\title{
Pengembangan Media Pembelajaran Berbasis Adobe Flash Dalam Kompetensi Geometri 3D
}

\author{
Zesra $^{1}$ \\ ${ }^{1}$ SMK Negeri 1 Batanghari, Jambi, Indonesia
}

\begin{tabular}{l} 
Article Info \\
\hline Article history: \\
Received Mar 29, 2020 \\
Revised Apr 15, 2020 \\
Accepted Apr 22, 2020 \\
\hline
\end{tabular}

Keywords :

Adobe Flash

Media Pembelajaran

3D Geometri

\begin{abstract}
ABSTRAK
Tujuan penelitian: Bertujuan untuk menciptakan produk media animasi audiovisual dalam pembelajaran pembangunan ruang yang mampu menjadi solusi untuk kesalahpahaman siswa dalam memahami unsur-unsur berbagai bangunan ruang tiga dimensi di Sekolah Kejuruan.
\end{abstract}

\begin{abstract}
Metodologi: Desain pengembangan yang digunakan adalah dengan mengadopsi model pengajaran dan pembelajaran Dick dan Carrey dengan memanfaatkan sembilan langkah desain. Produk-produk dalam penelitian ini telah diuji dan direvisi oleh para ilmuwan materi dan media dan juga kompetensi dalam menggunakan media pengajaran dan pembelajaran terutama di sekolah-sekolah kejuruan oleh para guru dan siswa.
\end{abstract}

Temuan utama: Hasil dalam penelitian ini menunjukkan bahwa media yang dikembangkan dapat membantu siswa menemukan kesalahpahaman dalam menemukan konsep terbaik untuk memotivasi belajar yang lebih baik, pengajaran dan pembelajaran dapat menjadi efektif, dan efisien serta menarik.

Keterbaruan peneltian: Keterbaruan penelitian ini adalah pengembangan media pembelajaran menggunakan adobe flash yang mampu meningkatkan kompetensi geometri 3D.

This is an open access article under the $\mathrm{CC} B Y-N C$ license

\section{Corresponding Author:}

Zesra

SMK Negeri 1 Batanghari, Jambi, Indonesia

email : zesraa@gmail.com

\section{PENDAHULUAN}

Tujuan pendidikan di Indonesia dilakukan secara interaktif, inspiratif, dan memotivasi peserta didik untuk meningkatkan sumber daya yang beriman, bertakwa, berbudi pekerti, berdisiplin, bertanggungjawab, serta memiliki kecerdasan intelektual yang tinggi [1]. Guru yang berkualitas adalah guru yang memiliki kemampuan mewujudkan tujuan pendidikan nasional diantaranya memiliki kompetensi pedagogik, kompetensi kepribadian, kompetensi sosial dan kompetensi professional [2]. Kompetensi di atas tidak akan diperoleh guru bila dalam pembelajarannya guru tidak mengembangkan diri mengikuti perkembangan ilmu pengetahuan dan teknologi.

Mendesain pembelajaran berteknologi misalnya dengan mengubah paradigma lama dari pembelajaran sistem konvensional menjadi berbasis teknologi adalah bagian dari pengembangan itu sendiri [3]. Guru perlu mengkombinasikan pembelajaran berbasis eksperimen dan teori secara imbang agar pembelajaran dikelas tidak monoton [4]. Seperti pada mata pelajaran matematika di SMK, khususnya pada program studi keahlian teknologi komunikasi dan informatika ada standar kompetensi yang mestinya disampaikan melalui media. Kesulitan siswa mengimajinasikan unsur-unsur bangun ruang seperti bidang diagonal pada kubus, balok, prisma dan limas hingga saat masih ditemui oleh guru. Guru masih membelajarkan materi yang bersifat abstrak itu dengan cara konvensional [5]. Mengajarkan materi bangun ruang dimensi tiga pada media dua dimensi seperti menggambarkan kubus, balok, prisma dan limas di papan tulis atau pada kertas. Kesulitan siswa dalam memahami unsur-unsur bangun ruang seperti bidang diagonal yang berpotongan dalam ruang akan memunculkan kesalahtafsiran mereka. 
Peneliti menemukan di lapangan ada beberapa alternatif pembelajaran bangun ruang dimensi tiga yang bisa dijadikan asumsi dalam menjawab masalah tersebut. Diantaranya: 1) menggunakan benda langsung yang dibawa kehadapan siswa seperti membawa kerangka dari bahan kawat. 2) menggunakan benda tiga dimensi pada media dua dimensi seperti melukisnya di papan tulis atau mengikuti gambar yang ada pada buku teks. 3) memanfaatkan teknologi dalam pembelajaran yaitu mendesain melalui media animasi yang tersedia dalam software komputer dalam bentuk audio-visual.

Mengajarkan bangun ruang tiga dimensi pada media dua dimensi seperti melukiskan kubus di papan tulis, sebagian siswa tidak bisa memahaminya seperti konsep yang sebenarnya. Hal inilah akan menimbulkan miskonsepsi siswa dalam memahami unsur-unsur yang terdapat dalam bangun ruang tersebut. Artinya betapa sulitnya mengajarkan konsep bangun ruang dimensi tiga pada media dua dimensi. Dengan memanfaatkan teknologi dalam pembelajaran, mendesain melalui media animasi, mengidentifikasi bagian mana yang memerlukan perlakuan teknologi yang diikuti dengan menggunakan prinsip-prinsip pengembangan media seperti penyertaan audio visual, tentu akan menjadikan pembelajaran akan efektif, efisien dan berkualitas [6].

Mendesain media berpedoman pada dua belas prinsip-prinsip media [7]. Mendesain media tersebut dengan berorientasi pada pembelajaran yang efektif, efisien dan menarik adalah bentuk pengembangan desain pembelajaran yang memanfaatkan teknologi audio-visual [8]. Media Pembelajaran seperti ini memperlihatkan secara jelas unsurunsur spesifik dalam bangun ruang.

Tujuan pengembangan ini terciptanya sebuah produk media animasi audio-visual pada pembelajaran bangun ruang yang mampu menjadi solusi miskonsepsi siswa dalam memahami unsur-unsur dalam berbagai bangun ruang. Menimbulkan proses berfikir logis, efektif, terarah dan menyenangkan serta membantu guru meningkatkan kompetensinya adalah wujud dari manfaat penelitian ini.

\section{METODE PENELITIAN}

Metode yang digunakan dalam penelitian ini adalah penelitian dan pengembangan atau Research and Development [9]. Pemilihan ini dikarenakan metode ini digunakan untuk menghasilkan produk dan menguji keefektifan sebuah produk [10]. Dalam rancangannya media ini mengadopsi model pembelajaran Dick and Carrey dengan memanfaatkan sembilan langkah desain.

Peneliti melakukan pengembangan dengan menganalisi standar isi pembelajaran, yaitu geometri dimensi tiga atau bangun ruang. Subjek uji coba adalah siswa kelas XI SMK Negeri 1 Batanghari. Menyusun instrumen validasi baik untuk uji perorangan, kelompok kecil maupun kelompok besar. Instrumen juga dilengkapi untuk ahli materi dan ahli media. Setelah disusun, diujicoba perorangan dengan mewawancarai lima siswa dengan tiga pertanyaan. Ranah pertanyaan adalah kejelasan tujuan materi, urutan materi dan kesesuaian animasi dengan pesan materi [11]

Data yang diperoleh dari uji coba perorangan adalah input untuk revisi pertama, Hasil ujicoba yang direvisi, divalidasi pada kelompok kecil dengan jumlah siswa sepuluh orang di kelas XI. Input data yang dikumpulkan dianalisis sehingga muncul revisi ketiga, Hasil revisi ketiga dijadikan bahan untuk memperbaiki instrumen pada ujicoba kelompok besar dengan jumlah tigapuluh satu siswa kelas XI. Input data digunakan untuk mendapatkan data kelayakan produk yang dihasilkan dan pada langkah ini terjadi revisi keempat. Input data pada tahap ini yang peneliti dapatkan tidak ada lagi revisi baik materi maupun media.

\section{HASIL DAN PEMBAHASAN}

Berdasarkan tahap-tahap yang dilakukan mulai dari uji perorangan hingga uji lapangan diperoleh hasil perlu disertai tambahan narasi, sedang instrumen validasi untuk uji ahli materi merekomendasikan bahwa produk perlu dilampiri dengan LKS dan ahli media menambahkan perlu ditambahkan music ringan dan narasi dengan memperhatikan prinsip-prinsip serta kriteria pengembangan media audio visual. Pada prinsipnya kedua ahli menyatakan instrumen layak untuk diujicobakan pada tahap selanjutnya.

Pada tahap uji coba perorangan diperoleh data tentang kejelasan tujuan materi, urutan materi dan kesesuaian animasi dengan pesan materi yang menunjukkan bahwa kejelasan tujuan materi sangat sesuai, urutan penyajian materi sangat sesuai dan kesesuaian animasi dengan materi juga sangat sesuai. Untuk melihat kualitas unsur-unsur media diperoleh data dari ujicoba kelompok kecil dimana 82,50\% siswa menanggapi bahwa kualitas unsur-unsur dalam produk sangat sesuai. Sedang pada kualitas pesan yang disampaikan dalam media melalui uji lapangan diperoleh informasi $85,61 \%$ siswa menanggapi sangat sesuai.

Yang lebih menakjubkan adalah pada aspek kemenarikan media pembelajaran bahwa 100\% siswa menanggapi sangat tertarik dengan produk ini. Mereka lebih termotivasi untuk belajar dengan menggunakan media dari pada belajar melalui buku khususnya dalam memahami unsur-unsur bangun ruang dalam geometri dimensi tiga [12-14]. Dengan media mereka dapat mengkonstruk sendiri pikiranya melalui indera [15-17]. Keinginan mereka 
untuk mempelajari materi menjadi lebih baik karena softcopiannya beserta bahan penyerta belajar berupa LKS bisa dibawa ke rumah.

Pada bagian lain sebagian besar mereka menginginkan pembelajaran seperti ini terus dikembangkan oleh guru-guru sebagai alat mempercepat pencapaian target ketuntasan belajar bagi mereka[18-21]. Hal ini bersesuaian pula dengan UU RI Nomor 14 tahun 2005 tentang Guru dan Dosen, yang mana guru harus selalu mengembangkan diri melalui kompetensi yang harus dimilikinya, salah satunya adalah kompetensi professional.

\section{KESIMPULAN}

Melakukan analisis kebutuhan dari media apa yang akan dibuat atau diproduksi dari sebuah pembelajaran adalah langkah pertama yang harus dilakukan agar didapatkan media yang baik. Analisis dimaksud meliputi analisis kurikulum, dari hasil analisis ini dikembangkan sebuah media baru dengan memanfaatkan pendapat yang direkomendasikan oleh ahli materi maupun media dengan simpulan sebagai berikut:

1) Media yang tepat untuk membelajarkan materi bangun ruang berdimensi tiga kepada siswa harus didesain dengan memanfaatkan teknologi dalam bentuk media animasi. Dengan animasi bangun ruang dan unsur-unsurnya terlihat lebih jelas dan menarik, sehingga pembelajaran lebih efektif, efisien dan menarik [17].

2) Pembelajaran bangun ruang dengan memanfaatkan media adobeflash pada program studi keahlian teknik komputer dan informatika di SMK layak digunakan sebagai salah satu cara mencapai tujuan pembelajaran.

3) Daya tarik media dapat dijadikan sebagai salah satu cara pencapaian tujuan pembelajaran dengan media pembelajaran berbasis adobeflash pada kompetensi geometri dimensi tiga.

4) Pemanfaatan media dalam pembelajaran menjadi akan menarik setelah memperhatikan aspek narasi, gambar, teks, animasi, warna, padat dan terstruktur.

5) Media yang dikembangkan sebagai media pembelajaran telah memperhatikan efektifitasnya dan mengikuti prinsip-prinsip dan prosedur kajian teknologi informatika.

Sebagai sara bagi pengguna media ini ada beberapa hal yang harus menjadi perhatian:

1) Media pembelajaran ini dapat dimanfaatkan oleh siswa dan guru secara luas dalam artian kapan dan dimana saja, sebaiknya di-upload melalui World Wide Web sekolah atau guru.

2) Karena media ini hanya digunakan oleh SMK program studi teknik komputer dan informatika maka sebaiknya dalam pemanfaatannya memperhatikan karakteristik siswa dimasing-masing satuan pendidikan.

3) Media ini juga berisikan audio, sebaiknya gunakan perangkat yang nyaman dan memenuhi syarat audio yang baik.

\section{UCAPAN TERIMA KASIH}

Ucapan terima kasih diberikan kepada pemberi dana penelitian atau donatur. Ucapan terima kasih juga disampaikan kepada pihak-pihak yang membantu dalam pelaksanaan penelitian.

\section{REFERENSI}

[1] P. D. Damanik, dan N. Bukit, "Analisis Kemampuan Berpikir Kritis dan Sikap Ilmiah Pada Pembelajaran Fisika Menggunakan Model Pembelajaran Inquiri Training (IT) dan Direct Instruction (DI)”, Jurnal Online Pendidikan Fisika, vol. 19. 2013.

[2] UU RI Nomor 14 tahun 2005 tentang Guru dan Dosen

[3] A. Arsyad, "Media Pembelajaran". Jakarta: Raja Grafindo Persada, 2010

[4] Astalini, D.A. Kurniawan dan Z. N. F Linda, "Deskripsi Sikap Siswa SMA di Batanghari berdasarkan Indikator Normalitas Ilmuwan, Adopsi dari Sikap Ilmiah, Ketertarikan Memperbanyak Waktu, dan Ketertarikan Berkarir dibidang Fisika", Jurnal Riset dan Kajian Pendidikan Fisika, vol. 5, no. 2, pp. 73-80. 2019.

[5] R. Asyhar, "Kreatif Mengembangkan Media Pembelajaran". Jakarta: Gaung Persada, 2010.

[6] S. Mishra, "Interactive Multimedia in Education and Training". India: Indira Gandhi National Open Universcity, 2004

[7] R. Mayer, "Multimedia Learning Prinsip-prinsip dan Aplikasi-edisi terjemahan”, Cambridge University Press. Yogyakarta: Pustaka Pelajar, 2009.

[8] H. A. H. Sanaky, "Media Pembelajaran". Yogyakarta: Safria Insani Press, 2009

[9] R. C. Richey, "Design and Development Research, Methodes, Strategies and Issues". London: Lawrence Erlnaum Associates, Publishers, 2007.

[10] Sugiono, "Metode Penelitian Kuatitatif, Kualitatif dan Research and Development". Bandung: Alfabeta, 2008

[11] S. N. Sukmadinata, "Metode Penelitian Pendidikan”. Bandung: PT.Remaja Rasdakarya, 2008 
[12] Dimyati dan Mujiono, Belajar dan Pembelajaran. Jakarta: PT. Rineka Cipta, 2009

[13] Y. Munadi, "Media Pembelajaran, Sebuah Pendekatan Baru”. Jakarta: Gaung Persada Press, 2008

[14] W. Sanjaya, "Perencanaan dan Desain Sistem Pembelajaran". Jakarta: Kencana Prenada Media Group, 2009

[15] H. B. Uno, "Perencanaan Pambelajaran", Jakarta: PT Bumi Aksara, 2007

[16] M. D. Roblyer., dan H. A. Doering, "Integrating Education Technology Into Teaching Fifth Edition”. Pearson Allyn: United States, 2010

[17] Y. Miarso, "Menyemai Benih Teknologi Pendidikan”, Jakarta: Prenada Media, 2004

[18] R. Rahmayeni, "Kerja keras siswa dalam pelajaran sains”, Journal Evaluation in Education, vol. 1, no. 1, pp. 27-33, 2020.

[19] M. Corry, "Identifikasi religiusitas siswa di sma adhyaksa 1 jambi", Journal Evaluation in Education, vol. 1, no. 1, pp. 15$20,2020$.

[20] N. Neldawati, "Deskripsi lingkungan belajar siswa terhadap mata pelajaran fisika di sma ferdy ferry putra kota jambi", Journal Evaluation in Education, vol. 1, no. 1, pp 1-7, 2020.

[21] S. Hasrani, "Kreativitas siswa dalam mata pelajaran ipa”, Journal Evaluation in Education, vol. 1, no. 1, pp. 21-26, 2020. 